\title{
Penetrasi Teknologi Informasi dalam Pemilihan Kepala Daerah Serentak 2018
}

\author{
Agustina Cahyaningsih, Hendaryanto Wijayadi, \\ Ryan Kautsar ${ }^{1}$
}

\begin{abstract}
Abstrak
Tulisan ini menyibak sejauh mana penetrasi teknologi informasi berdasarkan tahapantahapan dalam pilkada mampu memenuhi tuntutan publik atas penyelenggaraannya yang berkualitas dan dapat dipertanggungjawabkan. Kajian ini penting untuk dilakukan karena pemanfaatan teknologi telah diterapkan di hampir semua aspek pengelolaan proses pemilihan. Perhelatan pilkada selalu menjadi perhatian besar publik, dimana terjadi peningkatan partisipasi aktif masyarakat, baik dalam proses pemilihan maupun pengawasan, dimulai dari tahun 2009 ketika pemanfaatan teknologi informasi dalam beberapa siklus pemilihan di Indonesia mulai digunakan. Dengan menggunakan tiga level indikator, yaitu tools, enabler, dan transformer untuk mengetahui tingkatan penetrasi pemanfaatan teknologi informasi apakah sudah memenuhi prinsip efektif, efisien, transparan, akuntabel, dan aksesibel. Pemanfaatan teknologi informasi merupakan sebuah kebutuhan terkini yang harus dipertimbangkan dalam penyelenggaraan pilkada yang inklusif dan aksesibel, baik bagi pemilih, peserta, maupun penyelenggara pilkada. Hasil penelitian menunjukkan bahwa aplikasi SITUNG masih dalam kategori tools dan aplikasi SIDALIH sudah masuk dalam level enabler. Dapat disimpulkan bahwa aplikasi tersebut merupakan hasil penetrasi teknologi informasi dalam pilkada, khususnya pada proses pemutakhiran data pemilih dan penyusunan daftar pemilih serta proses perhitungan suara. Implementasi kedua teknologi informasi dalam pilkada berkontribusi menghasilkan data pemilu yang akurat, meningkatnya partisipasi pemilih dan kepercayaan publik.
\end{abstract}

Kata Kunci: Penetrasi; Pilkada; Teknologi; Informasi

1 Agustina Cahyaningsih, Hendaryanto Wijayadi, dan Ryan Kautsar adalah mahasiswa Pascasarjana Ilmu Politik dan Pemerintahan, Universitas Gadjah Mada 


\section{Pendahuluan}

Perkembangan teknologi dan informasi telah mendorong sebagian besar lembaga/badan penyelenggara pemilu di dunia saling beradaptasi terhadap teknologi baru dengan tujuan untuk meningkatkan proses kepemiluan yang lebih kredibel. Teknologi hanya dapat memiliki dampak yang signifikan terhadap partisipasi politik apabila penggunaannya telah tersebar luas. ${ }^{2}$ Harapannya, penerapan teknologi dalam pemilu maupun pilkada akan membawa manfaat besar dalam keakuratan, kecepatan, efisiensi, dan keefektifan proses sebab teknologi dapat memfasilitasi masyarakat yang dulunya memiliki keterbatasan dalam hal akses dan partisipasi. ${ }^{3}$

Teknologi dapat diterapkan di hampir semua aspek pengelolaan proses tahapan pemilihan, dari 106 negara pengguna teknologi pemilu yang didata oleh International IDEA, 60\% di antaranya menggunakan teknologi untuk tabulasi perolehan suara, 55\% untuk pendaftaran pemilih, 35\% untuk biometrik (sidik jari, retina, dan lain-lain) pendaftaran pemilih, $25 \%$ untuk biometrik dalam verifikasi pemilih, dan $20 \%$ untuk e-voting. Tidak semua negara menerapkan teknologi secara penuh dalam seluruh rangkaian proses pemilu, masih ada penggabungan antara proses manual dan modern yang sesuai dengan kondisi di negaranya.

Pemanfaatan teknologi dalam penyelenggaraan pemilu memiliki tantangan dan risiko yang besar terhadap proses penyelenggaraannya. Kegagalan pemanfaatan teknologi dalam pemilu akan menyebabkan kredibilitas dan integritas proses dan hasil pemilu dipertanyakan, apalagi jika kegagalan penerapan teknologi tersebut pada tahapan-

2 R. M. Alvarez, Thad E. Hall, and Alexander H. Trechsel. (2009). Internet Voting in Comparative Perspective: The Case of Estoni. Political Sciences and Politics, Vol. 42, No. 3, (July 2009), 497-505.

3 K.Vassil \& T. Weber. (2011). A Bottleneck Model of E-Voting: Why Technology Fails to Boost Turnout. New Media \& Society, 13 (8), 1336-1354. 
tahapan yang krusial. ${ }^{4}$ Demikian juga dengan pemanfaatan teknologi pada penyelenggaraan pemilihan kepala daerah dan wakil kepala daerah serentak (pilkada). Sebagaimana diketahui, pemilihan kepala daerah dan wakil kepala daerah serentak gelombang 3 telah diselenggarakan pada tanggal 27 Juni 2018. Pesta demokrasi di tingkat lokal tersebut diikuti oleh 171 daerah yang terdiri dari 17 provinsi, 115 kabupaten, dan 39 kota di seluruh Indonesia. Melihat jumlah daerah yang melaksanakan pilkada cukup besar, maka dapat dipastikan bahwa pelaksanaan pilkada di seluruh tahapan membutuhkan sumber daya manusia, logistik, dan anggaran yang cukup besar. Hal tersebut berimplikasi terhadap timbulnya berbagai persoalan dalam pelaksanaannya. Secara umum, penyelenggaraan pilkada di tahun 2018 berlangsung dengan lancar dan kondusif meskipun ada beberapa gugatan sengketa pilkada di beberapa daerah. Mahkamah Konstitusi (MK) mencatat sebanyak 67 permohonan penyelesaian hasil pemilihan kepala daerah (pilkada) serentak $2018 .^{5}$

Berdasarkan uraian di atas, maka kajian ini penting untuk didiskusikan mengingat bahwa pemanfaatan teknologi informasi telah menjadi sebuah kebutuhan terkini yang harus dipertimbangkan untuk digunakan dalam penyelenggaraan pilkada. Pengalaman Indonesia dalam mengadopsi teknologi pada pemilu sudah berlangsung cukup lama sejak tahun 1999 meskipun masih dengan metode yang sangat sederhana, sampai saat ini dengan teknologi yang lebih modern. Oleh karena itu, dengan mengidentifikasi sejauh mana penetrasi pemanfaatan teknologi dalam penyelenggaraan pilkada, khususnya pada dua tahapan utama pilkada, yaitu tahapan registrasi atau pendaftaran pemilih dan tahapan perhitungan suara, maka hasil dari

4 A. J. Berinsky. (2005). The Perverse Consequences of Electoral Reform in the United States. American Politics Research, 33 (4), 471-491.

5 Yuliana Ratnasari, "Sengketa Hasil Pilkada 2018 di MK Capai 67 Permohonan Perkara”. https://tirto.id/Sengketa-Hasil-Pilkada-2018-Di-Mk-Capai-67-Permohonan-Perkara-Cpdu, diakses pada 2 Oktober 2018. 
kajian ini diharapkan dapat memberikan jawaban pada tingkatan mana penetrasi teknologi yang digunakan dalam pilkada mampu menjadi suatu teknologi yang ideal dalam supporting system proses pilkada atas permasalahan dalam daftar pemilih dan rekapitulasi perhitungan suara yang transparan, mudah diakses, serta dapat dipertanggungjawabkan dalam setiap tahapan penyelenggaraannya.

Penelitian ini dilakukan secara kualitatif dengan melakukan pengumpulan data menggunakan teknik dokumen, yaitu teknik pengumpulan data dengan sumber bukan manusia (non human resources), di antaranya dokumen, foto, dan bahan statistik yang telah didokumentasikan, kemudian dilengkapi dengan pengamatan atau observasi terhadap penyelenggaraan pilkada 2018, khususnya di dua tahapan, yaitu tahapan pemutakhiran data dan penyusunan daftar pemilih, serta rekapitulasi perhitungan suara berdasarkan teknis bekerjanya sistem atau teknologi yang digunakan.

\section{Aspek Penggunaan Teknologi}

Teknologi dapat digunakan untuk menciptakan berbagai bentuk inovasi guna memotong jalur birokrasi (by pass) dalam proses pemilihan. “Teknologi” dapat didefinisikan sebagai sesuatu yang melibatkan penerapan sains dan teknik. Definisi yang luas ini dapat mencakup setiap barang yang diproduksi, sehingga definisi yang lebih terbatas diadopsi untuk mempertimbangkan item yang secara langsung relevan dengan administrasi pemilu. ${ }^{6}$ "Teknologi baru” dapat berarti baru di satu tempat dan sudah dianggap usang di tempat lain, di samping menjadi konsep yang berkembang. Dalam penerapannya, problem yang dihadapi tidak sekadar efisiensi anggaran dan pengurangan tenaga manusia, tetapi juga bagaimana kesiapan sumber daya manusia yang akan terlibat dalam proses elektronisasi

6 Rhenald Kasali. (2017). Disruption: Tak Ada yang Tak Bisa Diubah Sebelum Dihadapi Motivasi Saja Tidak Cukup. Jakarta: Gramedia Pustaka Utama. 
pemilu yang membutuhkan profesionalitas penyelenggara pemilu yang memahami penggunaan teknologi Internet of Things (IOTs). "Pemilu dan teknologi” sering mengacu pada program perangkat lunak atau software dan perangkat keras atau hardware, seperti komputer, printer, scanner, dan internet. Namun dalam pemilu, ada teknologi lain yang digunakan, yang tidak secara langsung melibatkan komputer tetapi memiliki andil sama pentingnya, seperti aluminium, kayu, kardus, duplex, dan plastik yang digunakan sebagai peralatan pemungutan suara.

Kajian lain terkait penggunaan teknologi dalam pemilu oleh Mc. Cormack, memosisikan peran teknologi sebagai think tank kebijakan, yaitu mempertanyakan cara terbaik dalam memastikan penerapan teknologi di negara-negara besar dan kecil dengan tujuan meningkatkan akses, memperluas partisipasi, dan memperkuat kredibilitas demokrasi. ${ }^{7}$ Dalam penyelenggaraan pemilu secara keseluruhan, relatif belum tersentuh oleh kemajuan teknologi karena masih ada pro dan kontra di sebagian negara yang telah menggunakannya. Pemerintah dan para pemilih masih dalam pergulatan dengan cara bagaimana mereka merangkul era Digital agar memiliki manfaat sementara yang didapatkan, seperti menjaga integritas dan legitimasi serta memastikan penguatan demokrasi.

Ada empat pertimbangan mengapa teknologi harus diadopsi untuk memperkuat proses pemilihan, di antaranya:

1. Akurasi hasil perhitungan suara: Tindakan pencegahan kecurangan dalam pengisian surat suara menjadi perhatian utama dalam setiap pemilihan elektronik. Dengan mengurangi atau menghilangkan kesalahan manusia pada proses yang dilakukan secara manual, telah terbukti memberi dampak positif

7 Conny McCormak. (2016). Democracy Rebooted: The Future of Technology in Elections. Washington: Atlantic Council. 
di negara yang berhasil mengimplementasikan pemungutan suara secara elektronik.

2. Mengurangi kerusakan suara: Sistem voting elektronik dapat mengingatkan pemilih tentang suara tidak sah sebelum pemungutan suara akhir, mencegah pemungutan suara yang tidak disengaja, dan mengurangi kesalahan. Sistem elektronik akan mengurangi pemakaian kertas surat suara, yang apabila dipersentasekan jumlah pemborosan suara atau suara terbuang dengan alasan tidak sah antara 3-7 \% di seluruh dunia.

3. Kecepatan dalam melahirkan kepercayaan diri: Rilis hasil perhitungan suara yang cepat akan meningkatkan kepercayaan pemilih di proses perhitungan dan meningkatkan legitimasi atas hasil elektoral. Segala penundaan dalam tahapan ini dapat menimbulkan kecurigaan dan ketidakpercayaan, dan secara historis, berkontribusi atas ketidakpercayaan publik, yang dapat membuat masyarakat sipil terjebak dalam kerusuhan dan kekerasan.

4. Aksesibilitas meningkatkan inklusi: Adanya ketersediaan fasilitas pemungutan suara yang akses bagi pemilih disabilitas dan lanjut usia sehingga memungkinkan semua pemilih dapat memberikan suara atas pilihan mereka.

IDEA juga menggarisbawahi pemanfaatan teknologi dalam pemilu akan membawa manfaat besar dalam keakuratan, kecepatan, efisiensi, dan keefektifan proses. Di satu sisi, mereka juga menghadirkan tantangan di bidang keamanan, biaya, keberlanjutan, transparansi, dan ketergantungan vendor. ${ }^{8}$ Manfaat penggunaan teknologi secara singkat digambarkan dengan "the bathtub curve atau kurva bak mandi" yang menunjukkan bahwa dibutuhkan waktu persiapan yang panjang

8 IDEA. (2006). Desain Penyelenggaraan Pemilu. Buku Pedoman Internasional IDEA, 257283. 
untuk pengenalan teknologi dalam pemilu guna memastikan fase burn in/terbakar dapat berlangsung sebelum hari pemilihan. Dan, bahwa waktu antara pemilihan harus digunakan untuk mengidentifikasi dan mengimplementasikan semua upgrade yang diperlukan untuk periode pemilihan berikutnya. Sementara, sebagian besar sistem non pemilu akan digunakan terutama selama fase kedua dari kurva ini.

Sifat pemilihan yang sporadis menyiratkan bahwa teknologi pemilu akan sering digunakan hanya sesaat setelah perkembangannya dan mungkin masih berada dalam fase burn in yang rawan kegagalan. Pada fase useful life/manfaat, adalah ketepatan dengan waktu antara pemilihan ketika sistem tidak digunakan. Dan ketika pemilihan berikutnya terjadi, setelah beberapa tahun, sistem mungkin sudah mendekati tingkat kegagalan dalam fase wear out /keausan.

Herald Setiadi juga menaruh perhatian pada persoalan penggunaan teknologi informasi dalam konteks e-democracy berdasarkan pandangan bisnis, politik, dan rakyat.' Dalam pandangan bisnis, pesta demokrasi telah memberikan manfaat bagi unit-unit bisnis skala kecil maupun besar. Dalam pandangan politik, teknologi informasi digunakan sebagai alat kampanye dan propaganda atau kepentingan politik lainnya, sedangkan dalam pandangan rakyat, proses demokrasi yang baik akan berujung pada kesejahteraan bangsa. Berdasarkan ketiga pandangan ini, kemunculan teknologi informasi diharapkan dapat memberikan efek yang baik dalam membangun e-democracy. Oleh karena itu, perlu perencanaan yang matang dalam membangun sistem demokrasi atas dasar kerahasiaan, transparansi, kejujuran, keadilan, kecepatan, dan ketepatan informasi tentang penyelenggaraan pemilu. Perkembangan teknologi, khususnya teknologi informasi dan komunikasi diharapkan dapat menyemarakkan dan meningkatkan partisipasi masyarakat dalam kegiatan demokrasi. Namun, teknologi bukanlah tanpa cacat.

9 Herald Setiadi. (2009). Menuju Demokrasi Dengan Teknologi Informasi. Makalah disajikan dalam Seminar Nasional Informatika. Yogyakarta: UPN Veteran. 
Jika teknologi dirancang tidak sesuai dengan kebutuhan, maka akan memperpanjang kegagalan proyek IT, menghambat proses tahapan, menambah biaya dan penurunan produktivitas.

\section{Pemanfaatan Teknologi di Berbagai Negara}

\section{Rusia}

Central Election Commission (CEC) of Russia/"KPU” Rusia mulai menggunakan sistem informasi pendataan penduduk yang diberi nama GAS (Geographically Automated System) "Vybory". ${ }^{10}$ Fungsi utama GAS "Vybory" adalah melakukan proses otomatisasi basis data informasi pemilih pemilu dan mendukung persiapan di setiap tahapan pemilu serta referendum, dimana sistem ini memberikan jaminan informasi yang autentik, proses pemilu yang transparan, jaminan ketepatan waktu, keakuratan proses pemilu, dan sebagainya. Pada tahun 2004, GAS "Vybory" telah digunakan di enam pemilu Federal, dengan lima pemilihan deputies of the State Duma, 122 pemilu provinsi, dan 1.358 pemilu kabupaten/kota. Pada tahun 2005, empat pemilu Federal menggunakannya, 90 pemilu provinsi, dan 2.500 pemilu kabupaten/ kota. Dioperasikan oleh 3.000 tenaga IT, GAS “Vybory” kini tersebar di 89 negara Federal Rusia.

\section{Amerika}

Di Amerika Serikat, Federal Election Commission (FEC)/"KPU" Amerika memiliki otoritas untuk menggunakan data dari Department of Motor Vehicle (departemen yang meregistrasi kendaraan bermotor), yang disebut layanan "Motor Voter", dimana sumber data pemilih di Amerika merupakan kombinasi dari data yang ada tanpa harus mempermasalahkan sumber itu datang hanya dari satu sumber. Untuk proses pemungutan suara pada pemilu, Amerika telah menggunakan e-voting atau electronic voting yang memungkinkan pemilih memberikan

10 Central Election Commission of The Russian Federation, State Automated System of the Russian Federation "VYBORY”. (2011). Moscow. 
suara secara elektronik. Sistem tersebut dipercaya lebih efisien dari segi biaya dan mampu meningkatkan partisipasi masyarakat.

\section{India}

Election Commision of India/"KPU” India bekerja sama dengan pemerintahan India membuat sebuah terobosan teknologi yang dinamakan National Voter's Service Portal (NVSP) sebagai pelayanan terpadu satu pintu terhadap para pemilih. ${ }^{11}$ Sistem penyusunan daftar pemilih di India menganut sistem stelsel aktif, dimana warga negara yang harus melakukan pengecekan \& pendaftaran atas data mereka yang sudah didaftar oleh negara. NVSP bertujuan untuk meningkatkan transparansi, kemudahan akses atas informasi, mempermudah melakukan pendaftaran dan koreksi (easy registration, easy correction). Dengan desain antarmuka yang ramah dan tampil dalam sekejap mata, memudahkan penduduk India dalam pencarian-pencarian mengenai pemilihan nasional di lebih dari 85 data pemilih inti.

\section{Teknologi Informasi dan Pemilu di Indonesia}

Perkembangan teknologi informasi dan komunikasi merambah digitalisasi di berbagai bidang, termasuk dalam ranah electoral, yaitu dalam pemilu. Tujuan awal penggunaan teknologi informasi dalam pemilu adalah untuk memudahkan proses dan menerapkan transparansi. Di Indonesia, pemanfaatan teknologi informasi pada penyelenggaraan pemilu telah ada sejak tahun 1999 dalam proses tabulasi atau rekapitulasi hasil perhitungan suara nasional, kemudian mulai dikembangkan secara intensif di pemilu 2004 hingga pemilu terakhir tahun 2014. Sedangkan untuk penggunaan teknologi dalam penyusunan daftar pemilih, mulai digunakan pasca pemilu 2009, karena di tahun tersebut muncul persoalan pada data pemilih yang menarik perhatian publik.

Mendasari persoalan tersebut, kemudian dikembangkan sistem

11 http://eci.gov.in/ diakses 9 Desember 2018. 
pengelolaan data pemilih berbasis teknologi yang melibatkan banyak pihak, seperti BPPT (Badan Pengakajian dan Penerapan Teknologi), Kemendagri, Perwakilan LSM, Perwakilan Perguruan Tinggi, dan Perwakilan KPU provinsi yang tergabung dalam Prakarsa Pendaftaran Pemilih KPU. Kegiatan yang dilakukan Prakarsa Pendaftaran Pemilih KPU antara lain melakukan kajian terhadap peraturan perundangundangan, kajian terhadap sistem pendaftaran pemilih di negaranegara sahabat, melakukan FGD (Focus Group Discussion) di beberapa wilayah di Indonesia, seminar publik, dan menyelenggarakan uji coba terhadap sistem pendaftaran pemilih berbasis teknologi yang dihasilkan di beberapa wilayah.

Terkait dengan hasil pemilu, tahun 2014 menjadi momentum penting dalam perluasan penggunaan teknologi dalam pemilu. Salah satu buktinya adalah penerimaan penghargaan dari Lembaga Partnership for Governance Reform kepada KPU atas penerapan prinsip transparansi dan akuntabilitas data pemilu 2014. Hal tersebut menjadi bukti bahwa penggunaan teknologi informasi dalam penyelenggaraan pemilu, terutama proses pendaftaran pemilih yang menggunakan aplikasi SIDALIH (Sistem Informasi Data Pemilih) dan rekapitulasi perhitungan suara yang menggunakan SITUNG (Sistem Informasi Perhitungan Suara) turut menyumbang keberhasilan pemilu di tahun 2014.

Sistem Informasi Data Pemilih (SIDALIH) merupakan sebuah aplikasi yang dikembangkan pada tahun 2011 untuk menjawab permasalahan daftar pemilih pada pemilu legislatif dan pemilu presiden 2009, yang pada waktu itu sempat menuai banyak protes sehingga menjadi sorotan publik. Kondisi pasca pemilu 2009, KPU tidak memiliki basis data tunggal yang terpusat dan terintegrasi, masing-masing KPU provinsi dan kabupaten/kota memiliki basis data sendiri dan berbeda satu sama lain, baik dari segi format dan teknologi 
yang digunakan. Selain itu, DP Tools $^{12}$ sebagai aplikasi yang digunakan untuk memutakhirkan data pada waktu itu tidak memiliki kemampuan berintegrasi dengan aplikasi yang sama di tempat lain, sehingga data yang diolah berisiko mengalami duplikasi. Kondisi tersebut menyebabkan perubahan yang terjadi pada tingkat pemutakhiran tidak dapat diketahui dan dipantau cepat oleh para pemangku kepentingan yang berada di lokasi yang berbeda.

Keunggulan dari SIDALIH dan perbedaannya dengan caracara sebelum ini, sebagaimana dari pemilu ke pemilu yang telah diselenggarakan adalah pertama, mampu mengakhiri sebagian besar silang sengkarut problematika terkait tahapan pemutakhiran daftar pemilih. Dengan adanya SIDALIH, KPU mampu menjelaskan berapa jumlah angka-angka besaran daftar pemilih. Yang selama ini tidak pasti menjadi lebih memastikan setelah menggunakan SIDALIH untuk pembersihan data-data dari hasil pemutakhiran Daftar Penduduk Pemilih Potensial Pemilu (DP4) yang diserahkan oleh Kementerian Dalam Negeri dan/atau Pemerintah Daerah (pemprov, pemkab/kota).

Kedua, dengan dikeluarkannya UU Pemilu No. 8 Tahun 2012 di Pasal 32 yang menyatakan "Dalam memutakhirkan DP4 menjadi Daftar Pemilih Sementara (DPS), dimungkinkan bagi KPU untuk mengacu terhadap data terakhir pemilih dalam pemilu kepala daerah dan wakil kepala daerah.” Kebijakan untuk menggunakan SIDALIH dalam rangka memutakhirkan data pemilih sangat membantu penyelenggara pemilu. Sebagai contoh, dengan bantuan SIDALIH, KPU berhasil menstrukturalisasi data kependudukan yang bermasalah ketika diharuskan menjadi daftar pemilih sejumlah 60 juta nama warga negara yang berhak menjadi pemilih namun belum memiliki

12 DP Tools adalah tools yang dibuat pada tahun 2009 untuk membantu KPU dalam menganalisis dan memutakhirkan Daftar Pemilih (DP) sebelum ditetapkan menjadi Daftar Pemilih Sementara (DPS) dan Daftar Pemilih Tetap (DPT) pada Pemilu Presiden dan Pilkada. 
NIK. Kemudian, berhasil mengidentifikasi 17 juta nama pemilih yang telah meninggal dunia dari sebanyak 185.296.741 juta pemilih yang akhirnya ditetapkan oleh KPU pada 23 Oktober 2013 yang sebelumnya oleh Kemendagri diserahkan berupa DP4 kepada KPU sejumlah 187 juta. ${ }^{13}$ Pada RDP KPU bersama dengan Komisi II DPR RI, DP4 yang diterima pada tanggal 7 Februari 2013 mencakup pemilih dalam DP4 sebanyak 190.412.094 orang terdiri atas 95.971.913 laki-laki dan 94.440.181 perempuan.

Ketiga, hal paling penting dari SIDALIH adalah sistem operasinya yang bersifat terbuka (open data/open source), dapat diakses secara daring (online). Hal ini merupakan kelebihan tersendiri yang memungkinkan keterlibatan khalayak untuk melakukan pengecekan, perbaikan, dan kontroling dari masyarakat. Keempat, adalah fungsionalisasi SIDALIH dari konsolidasi data pemilih. ${ }^{14}$ SIDALIH berhasil mengoleksikan data-data pemilih dari seluruh jenis pemilu yang telah digelar mulai dari pemilu kepala daerah dan wakil kepala daerah sepanjang tahun 2015 dan 2017. Dengan SIDALIH, pengelolaan data dilakukan secara nasional.

Kelima, ketersediaan server tersendiri sebagai "basis data raksasa" dengan memanfaatkan kemajuan teknologi informasi dan komunikasi berbasis komputerisasi. Apabila data tersebut dirawat/dipelihara dengan baik dan terstruktur, maka perkembangan kependudukan yang memuat variabel peristiwa-peristiwa demografis, seperti angka kematian, kelahiran, dan perpindahan kelak memudahkan dalam menghasilkan data pemilih yang akurat, komprehensif, dan terkini (up-to-date).

Pemanfaatan teknologi berikutnya adalah pada proses rekapitulasi

13 Hasil Rapat Dengar Pendapat Komisi II DPR RI dengan KPU, Bawaslu, dan Kemendagri, Kompleks DPR RI, Oktober 2013.

14 Nur Hidayat Sardini. (2017). Mengeluarkan Pemilu dari Lorong Gelap (pp.151). Jakarta: Yayasan Pustaka Obor Indonesia. 
perhitungan suara, yaitu SITUNG. SITUNG (Sistem Informasi Perhitungan Suara) merupakan upaya untuk menciptakan kondisi yang kondusif selama proses perhitungan dan rekapitulasi berlangsung dalam pemilu. Sistem ini akan terbagi atas dua proses, yaitu proses pengumpulan dan proses penyajian data hasil pilkada dari seluruh TPS dengan cepat, akurat, dan transparan. SITUNG merupakan salah satu elemen substansial dari keseluruhan rangkaian penyelenggaraan pilkada. Rasa keingintahuan masyarakat luas akan hasil pemilu di semua tingkatan, baik di TPS sampai dengan tingkat nasional diredamkan sementara waktu dengan publikasi Form C1 yang ditampilkan dalam SITUNG segera setelah rekapitulasi di tingkat TPS selesai sampai hasil akhir resmi ditetapkan. Ada lima fungsi utama SITUNG, yaitu transparansi hasil pemilu, kecepatan hasil pemilu, publikasi hasil pemilu, meminimalisir kesalahan, dan pengawasan terhadap penyelenggara di setiap tingkatan.

Berdasarkan proses keterlibatan teknologi informasi, maka penetrasi teknologi informasi dalam pemilu dikategorikan menjadi tiga indikator, yakni sebagai tools, enabler, dan transformer. ${ }^{15}$ Berikut adalah penjelasan ketiga indikator tersebut.

1. Tools. Teknologi informasi yang digunakan masuk dalam kategori tools apabila berperan sebagai pendukung jalannya organisasi penyelenggara pemilihan dan proses komputerisasi dari back office meskipun dengan format yang masih sederhana. Di sini, teknologi informasi hanya menjadi pelengkap dalam tahapan pemilihan.

2. Enabler terwujud jika teknologi informasi sudah menjadi penggerak tahapan pemilihan karena sudah pada tahap perluasan informasi serta membuahkan efisiensi yang signifikan dalam penyelenggaraan pemilihan. Penggunaan aplikasi TI dari sekadar

15 Lukito Edi Nugroho. (2009). Pemanfaatan Teknologi Informasi di Perguruan Tinggi. Yogyakarta: Prajnya Media. 
membantu dan mengotomatisasi pekerjaan hingga mendukung pengambilalihan keputusan.

3. Transformer, yaitu teknologi informasi telah menjadi penentu arah transformasi penyelenggaraan pilkada menuju efektivitas pemilihan, reduksi biaya dan waktu secara signifikan dengan prinsip otomatisasi, dan rekayasa ulang proses (process re-engineering). Untuk mencapai level ini, dibutuhkan konsistensi pada proses perbaikan untuk mencapai kesempurnaan penetrasi yang diharapkan.

Indikator tools berada di level paling bawah, kemudian diikuti oleh enabler pada taraf sedang, dan level tertinggi adalah transformer. Dengan melakukan analisis terhadap bentuk teknologi informasi yang digunakan dalam pemilu maupun pilkada, berdasarkan cara bekerjanya, manfaat, dan kendala apa saja yang didapatkan pada saat implementasi teknologi tersebut, selanjutnya didapatkan bukti-bukti untuk memenuhi persyaratan ketiga kategori tadi, sebagai tingkatan penetrasi teknologi informasi.

\section{Teknologi Informasi dan Pilkada 2018 Pemilihan Kepala Daerah (Pilkada) di Indonesia}

Pemilihan gubernur, bupati, dan walikota yang selanjutnya disebut pemilihan adalah pelaksanaan kedaulatan rakyat di provinsi dan kabupaten/kota untuk memilih gubernur, bupati, dan walikota secara langsung dan demokratis, sedangkan pengertian dari pemilihan kepala daerah (pilkada) adalah pelaksanaan dari tahapan pemilihan gubernur, bupati, dan walikota yang diselenggarakan oleh penyelenggara pilkada. Seluruh tahapan penyelenggaraan pilkada harus dilaksanakan dengan tepat waktu dan semua informasi penyelenggaraan pilkada wajib disampaikan kepada masyarakat luas. Dalam konteks konsolidasi dan penguatan demokrasi, pilkada langsung menjadi pilar yang memperkukuh bangunan demokrasi secara nasional. Terlaksananya 
pilkada langsung menunjukkan adanya peningkatan demokrasi karena rakyat secara individu dan kelompok terlibat dalam proses melahirkan pemerintah atau pejabat negara.

Pemilihan kepala daerah (pilkada) sebagai rangkaian mekanisme yang sangat kompleks, melibatkan banyak pihak dalam menentukan masa depan sebuah masyarakat di tingkat lokal, yang dilakukan secara langsung. Sebagai instrumen politik, momentum pilkada langsung ini memberikan kewenangan sepenuhnya kepada KPU untuk mengurus berbagai hal yang berkaitan dengan pemilihan. Sebagai ruang partisipasi publik, ada tujuh prinsip dasar fundamental bagi KPU dalam melakukan tata kelola pemilihan, yaitu impersialitas, independen, integritas, profesional, transparansi, efisiensi, dan berorientasi pada pelayanan. Implementasi proses pemilihan berdasarkan pada tujuh prinsip tersebut akan menentukan tingkat legitimasi pilkada. KPU bertanggung jawab terhadap terpenuhinya hak pilih warga negara sebagai bentuk partisipasi politik aktif mereka dalam proses pembuatan dan pelaksanaan keputusan politik.

Pelaksanaan pilkada dituntut untuk sukses dalam setiap tahapannya, dengan berbagai permasalahan dan kesulitan yang ada. Hal ini sejalan dengan prinsip-prinsip yang menjadi pedoman utama penyelenggaraan pilkada 2018 sesuai dengan Undang-Undang No. 10 Tahun 2016 tentang Pemilihan Gubernur, Bupati, dan Walikota. Disebutkan bahwa penyelenggaraan pilkada dilaksanakan secara efektif dan efisien berdasarkan asas langsung, umum, bebas, rahasia, jujur, dan adil. Pemenuhan prinsip-prinsip tersebut akan menjamin legitimasi dan kredibilitas proses pilkada.

Prinsip-prinsip di atas membentuk dasar bagi penyelenggaraan pilkada dan sangat esensial untuk menjamin integritas dan legitimasi proses pilkada. Tahapan penyelenggaran pilkada tahun 2018 di Indonesia terdiri atas dua tahapan, yaitu tahapan persiapan dan tahapan 
penyelenggaraan. Kegiatan yang krusial dalam tahapan persiapan adalah proses pemutakhiran data dan penyusunan daftar pemilih, sedangkan dalam tahapan penyelenggaraan, proses perhitungan suara masuk juga menjadi faktor penentu kualitas pilkada.

\section{Penggunaan Teknologi dalam Proses Penyelenggaraan Pilkada}

Harapan supaya bisa mengulang kembali kesuksesan pemilu 2014, maka KPU mengembangkan teknologi informasi berdasarkan kebutuhan dan kondisi terkini untuk meningkatkan kualitas pilkada yang digelar pertama kali secara serentak di tahun 2015 sampai dengan pilkada 2018. Pilkada 2015 merupakan pilkada yang digelar pertama kali secara serentak, dianggap sebagai pilkada yang paling terbuka sepanjang sejarah pemilu di Indonesa. Atas penggunaan teknologi dalam pilkada, berbagai keterbukaan data yang dilakukan oleh Bawaslu maupun KPU, seperti pembukaan akses terhadap data atau profil peserta pemilu/pilkada, data rekapitulasi, dan data daftar pemilih telah memperkuat prinsip transparansi dan akuntabilitas penyelenggaraan pilkada 2015. ${ }^{16}$ Keterbukaan informasi dan komunikasi secara tidak langsung telah meningkatkan kesadaran masyarakat untuk peduli pada masalah politik. Selanjutnya, memungkinkan terjadi interaksi dan partisipasi masyarakat memanfaatkan data tersebut untuk kepentingan mengawal proses pemilu dari hulu ke hilir. Oleh karena itu, pemilihan dan desain teknologi pilkada dalam berbagai bentuk yang ditujukan untuk meningkatkan partisipasi dan meningkatkan komunikasi perlu dipertimbangkan secara matang dengan mengikuti tuntutan publik yang semakin kompleks. Teknologi informasi yang digunakan dalam proses penyelenggaraan pilkada dirancang dan digunakan untuk

16 Diah Setiawaty dan Sebastian Vishnu Bhaskara. "Pengaruh Keterbukaan Data terhadap Inovasi, Gerakan Sosial, dan Partisipasi Politik dalam Pilkada Serentak 2015”. Jurnal Perludem. \#8, April 2016. 
meningkatkan konektivitas yang terintegrasi di antara penyelenggara pilkada dari tingkat provinsi sampai dengan tingkat desa/kelurahan. Perbaikan proses pilkada di segi digital berpotensi meningkatkan produktivitas hasil pilkada.

Konflik pilkada sering kali disebabkan oleh permasalahan DPT yang tidak akurat serta dugaan manipulasi dalam perhitungan suara dan rekapitulasi hasil perhitungan yang terjadi di setiap tingkatan mulai dari KPPS, PPS, PPK, KPU kab/kota, dan KPU provinsi. Persebaran TPS dalam wilayah yang sangat luas menjadikan faktor kontrol menjadi penting untuk menjaga keutuhan suara rakyat. Oleh karena itu, dalam penyelenggaraan pilkada, penggunaan teknologi juga dimanfaatkan untuk menyukseskan terselenggaranya pemilihan yang demokratis berdasarkan asas langsung, umum, bebas, rahasia, jujur, dan adil.

\section{Penetrasi Teknologi dalam Proses Pemutakhiran Data dan Penyusunan Daftar Pemilih}

Pemutakhiran data pemilih pilkada 2018 sesuai dengan yang tercantum dalam Peraturan KPU Nomor 2 Tahun 2017 adalah kegiatan untuk memperbaharui data pemilih berdasarkan Daftar Pemilih Tetap (DPT) dari pemilu atau pemilihan terakhir dan mempertimbangkan DP4 dengan cara melakukan verifikasi faktual data pemilih dan selanjutnya, digunakan sebagai bahan penyusunan DPS yang dilaksanakan oleh KPU/KIP kabupaten/kota dengan dibantu oleh PPK dan PPS. Daftar Penduduk Potensial Pemilih Pemilihan (DP4) merupakan data yang disediakan oleh pemerintah melalui Kementrian Dalam Negeri (Kemendagri).

Lebih lengkapnya, pemutakhiran data dan penyusunan daftar pemilih adalah kegiatan untuk memperbaharui, memperbaiki, dan mencatat data pemilih melalui proses pemutakhiran secara langsung. 
Kualitas DPT tergantung pada akurasi data yang disajikan, yaitu kebenaran bentuk dan isi data sesuai dengan standar yang telah ditetapkan. Secara teknis, pemutakhiran daftar pemilih adalah bentuk jaminan bagi pemilih untuk dapat menggunakan hak pilihnya.

Registrasi dan keakuratan daftar pemilih adalah hal yang penting karena terkait dengan aspek demokrasi, yakni keterwakilan dan penjaminan bahwa seluruh rakyat dapat menggunakan hak pilihnya, serta isu mengenai antisipasi kecurangan. Syarat utama sebagai pemilih adalah yang sudah terdaftar dalam daftar pemilih. Apabila tidak terdaftar dalam daftar pemilih, mereka pun potensial kehilangan hak kewarganegaraannya, yaitu hak politik untuk memilih yang berakibat pada penurunan tingkat partisipasi pemilih.

SIDALIH merupakan Sistem Informasi Data Pemilih berbasis online yang digunakan untuk mendukung kerja penyelenggara pilkada dalam menyusun, mengoordinasi, mengumumkan, memelihara data pemilih, dan melayani pemilih terkait data pemilih. Data pemilih yang dimaksud dalam pilkada adalah hasil sinkronisasi DPT pemilu atau pemilihan terakhir dan DP4 (Daftar Penduduk Pemilih Potensial Pemilu) hasil analisis KPU menggunakan formulir Model A-KWK dengan membagi pemilih di setiap TPS paling banyak 800 orang. Pelaksanaan pemutakhiran data pemilih dilaksanakan oleh KPU kabupaten/kota dibantu PPK dan PPS dalam menyusun data pemilih, DPS, DPT, DPTb, DPPH.

Fitur maupun kegunaan SIDALIH dalam pilkada tidak berbeda jauh dengan SIDALIH dalam pemilu 2014, antara lain terdapat fungsi utamanya, yaitu pemutakhiran, analisis kegandaan dan akurasi data, monitoring daftar pemilih, dan publikasi daftar pemilih. Untuk pilkada ada penambahan fungsi, yaitu managemen DP4, penanda dan klaim data ganda, jadwal serentak, dan jadwal tahapan. Dengan pemanfaatan teknologi informasi dalam proses pemutakhiran data dan 
penyusunan daftar pemilih, harapannya adalah untuk meningkatkan pelayanan publik dalam menyajikan daftar pemilih. Selain itu, juga untuk mempermudah pekerjaan penyelenggara pilkada dalam mengolah data pemilih secara lebih mudah, cepat, tepat, dan dapat dipertanggungjawabkan, serta transparan.

SIDALIH dalam pilkada dikembangkan agar digunakan oleh petugas PPS, PPK, KPU kab/kota dan KPU provinsi untuk pemutakhiran data pemilih secara terkomputerisasi, tanpa lagi perlu menggunting data pemilih dan mengelompokkan ke TPS secara manual. SIDALIH melakukan fungsi CRUDE (create, read, update, and dellete), dalam proses pemutakhiran data pemilih. Selain itu, SIDALIH memublikasikan daftar pemilih secara daring di laman KPU provinsi maupun KPU kab/kota. Yang tidak kalah penting adalah SIDALIH memiliki fitur monitoring yang sangat membantu KPU dalam memantau proses penyusunan daftar pemilih, memberikan informasi hasil analisa daftar pemilih secara nasional, yang berupa data potensi ganda dan data pemilih yang belum valid.

SIDALIH dikembangkan berbasis internet (web) bersifat tunggal dan terpusat di server KPU. Setiap KPU provinsi dan KPU kabupaten/ kota hanya diberikan akses untuk mengolah dan memutakhirkan data di wilayah kerjanya masing-masing pada saat tahapan pemutakhiran data pemilih berlangsung. SIDALIH dijalankan oleh operator di masingmasing KPU provinsi dan kabupaten/kota, dapat juga melibatkan anggota PPK sebagai operator di tingkat kecamatan. Dalam proses pemutakhiran data, tidak hanya menggunakan internet, tetapi dapat juga menggunakan aplikasi spreadsheet, seperti excel dengan format yang telah disesuaikan untuk kebutuhan aplikasi SIDALIH.

Dalam penerapan dan implementasi SIDALIH, KPU juga menemui beberapa kendala, antara lain infrastruktur jaringan internet dan listrik di beberapa wilayah di Indonesia belum seluruhnya 
memadai, sumber daya manusia baik dari sisi kualitas dan kuantitas untuk menjadi operator SIDALIH belum mencukupi, dan waktu yang tersedia sangat pendek dalam menyusun daftar pemilih. Karenanya, proses unggah data pemilih dalam sistem SIDALIH menyebabkan frekuensi yang sangat tinggi (crowded). Penggunaan teknologi informasi dalam pendaftaran pemilih dapat menjadi kontroversial karena beberapa alasan. Keakuratan daftar pemilih sering menjadi isu yang kontroversial. Dan, pembaruan teknologi dapat dilihat sebagai solusi untuk itu.

Seperti yang sudah dijelaskan di atas, penggunaan SIDALIH pada pilkada sebagai upaya memperbaiki kualitas daftar pemilih, juga menjadi alat untuk melaksanakan prinsip transparansi dan kemudahan akses terhadap daftar pemilih secara online, serta mampu mengonsolidasi jutaan data pemilih secara terpusat dan memutakhirkannya. Kemampuan teknologi men-disrupsi ${ }^{17}$ proses pemutakhiran manual hingga ke digital sudah menjadi penggerak tahapan pilkada serta membuahkan efisiensi yang signifikan dalam penyelenggaraan pilkada. Dengan demikian, teknologi dalam SIDALIH bisa dikategorikan sebagai teknologi yang enabler.

Berikut ini adalah skema proses pemutakhiran data pemilih pilkada yang telah menggunakan aplikasi SIDALIH dari awal data diperoleh hingga kemudian diolah dan disajikan. Intervensi teknologi informasi pada proses tersebut, sedikit demi sedikit mengurai kerumitan proses administrasi yang alurnya sangat panjang, membutuhkan waktu dan tingkat kecermatan yang tinggi, bahkan prosesnya harus melalui pengulangan, karena ada tahap perbaikan data sebelum data final ditetapkan.

17 Dalam kamus besar bahasa Indonesia, disrupsi didefinisikan hal tercabut dari akarnya. Jika diartikan dalam kehidupan sehari-hari, disrupsi adalah sedang terjadi perubahan yang fundamental atau mendasar. Satu di antara yang membuat terjadi perubahan yang mendasar adalah evolusi teknologi yang menyasar sebuah celah kehidupan manusia. 


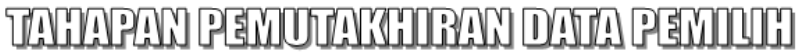

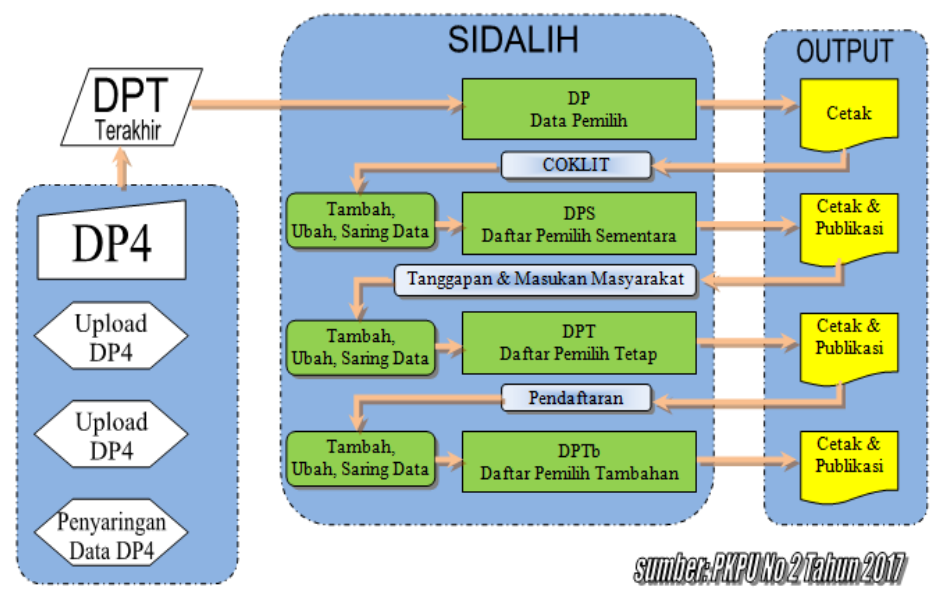

Sebagaimana diketahui penyusunan daftar pemilih dalam setiap penyelenggaraan pemilu maupun pilkada, selalu memiliki permasalahan dalam hal akurasi datanya. Persoalan dalam penyusunan daftar pemilih tersebut tetap tidak bisa dianggap hanya sebagai persoalan administratif, yang secara teknis menunjukkan kelemahan dan kekurangan implementasi kinerja lembaga penyelenggara pemilihan. Terlebih lagi sistem yang dianut di Indonesia adalah pendaftaran berdasarkan prakarsa negara (state-initiated registration), yaitu mix strategy, dimana pemerintah memfasilitasi proses pendaftaran pemilih yang juga dilakukan sendiri oleh pemilih. Prinsip yang dianut adalah para warga negara dan negara berbagi tanggung jawab dalam pendaftaran pemilih (citizens and the state share responsibility for registration). Fitur dalam aplikasi SIDALIH telah memenuhi prinsip tersebut. Dalam pengembangan selanjutnya, bisa dimungkinkan proses pendaftaran menggunakan prinsip negara mengambil langkah memfasilitasi pendaftaran pemilih untuk kemudian dilengkapi oleh pemilih (the state takes steps to facilitate registration, and citizens must do their part to complete the process). 
Untuk memberikan jaminan agar pemilih dapat menggunakan hak pilihnya, harus tersedia daftar pemilih akurat yang memenuhi standar kualitas daftar pemilih. Standar ini memiliki dua aspek, yaitu standar kualitas demokrasi dan standar kemanfaatan teknis. ${ }^{18}$ Dari aspek standar kualitas demokrasi, daftar pemilih hendaknya memiliki dua cakupan standar, yaitu pemilih yang memenuhi syarat masuk daftar pemilih dan tersedianya fasilitasi pelaksanaan pemungutan suara. Dari aspek standar kemanfaatan teknis, daftar pemilih hendaknya memiliki empat cakupan standar, yaitu mudah diakses oleh pemilih, mudah digunakan saat pemungutan suara, mudah dimutakhirkan, dan disusun secara akurat.

Setelah mengetahui bagaimana bekerjanya aplikasi SIDALIH, maka bisa disimpulkan bahwa penetrasi teknologi informasi pada SIDALIH dalam proses pendaftaran pemilih masuk dalam kategori enabler. SIDALIH telah membuka akses informasi kepada seluruh pihak yang berkepentingan dan penetrasi teknologi informasi juga dirasakan oleh KPU sebagai operator utama penyelenggaraan pilkada dalam hal efisiensi dan efektivitas. Dengan terpenuhinya ketiga aspek di atas, maka KPU sebagai pemilik teknologi, mendapatkan manfaat yang lebih tingggi sebagai akibat penetrasi teknologi informasi, yaitu terpenuhinya akuntabilitas pilkada sebagai bentuk pertanggungjawaban moral kepada publik. Pasal 7 Undang-Undang Nomor 28 Tahun 1999 menjelaskan bahwa yang dimaksud dengan "Asas Akuntabilitas" adalah asas yang menentukan bahwa setiap kegiatan dan hasil akhir dari kegiatan penyelenggara negara harus dapat dipertanggungjawabkan kepada masyarakat atau rakyat sebagai pemegang kedaulatan tertinggi negara sesuai dengan ketentuan peraturan perundang-undangan yang berlaku.

18 Ramlan Surbakti, Didik Supriyanto, Hasyim Ashari. (2011). Meningkatkan Akurasi Daftar Pemilih: Mengatur Kembali Sistem Pemilih Pemutahiran Daftar. Jakarta: Kemitraan bagi Pembaruan Tata Pemerintahan. 


\section{Penetrasi Teknologi pada Proses Perhitungan Perolehan Suara}

Tahapan perhitungan suara dapat dikatakan merupakan puncaknya pesta demokrasi dari keseluruhan proses pemilu maupun pilkada. Tahapan ini berujung pada hasil akhir perolehan suara untuk menetapkan pemenang pemilu. Proses perhitungan suara pada pilkada tidak ada perbedaan dengan proses perhitungan suara pada pemilu sebelumnya. Perhitungan suara di Tempat Pemungutan Suara (TPS) dilakukan ketika proses pemungutan suara telah selesai dilaksanakan, di hari yang sama dengan hari pemungutan suara.

Tahapan perhitungan suara di TPS dilakukan oleh petugas KPPS (Kelompok Penyelenggara Pemungutan Suara) dengan cara membuka satu per satu surat suara yang telah dicoblos oleh pemilih, lalu menuliskan satu per satu perolehan suara calon pada papan besar (formulir Plano), dan setelah selesai, selanjutnya menuangkan hasilnya pada berita acara dan sertifikat perolehan suara (formulir Model C, C1, dan lampiran C1). Proses perhitungan suara tidak hanya diikuti oleh petugas dan saksi, tetapi juga terbuka bagi masyarakat pemilih dan pemantau. Setelah perhitungan suara di TPS, selanjutnya dilakukan rekapitulasi hasil perhitungan suara secara berjenjang mulai dari rekapitulasi di Panitia Pemilihan Kecamatan (PPK), hasil rekapitulasi di PPK (formulir DA1) di rekapitulasi di KPU kabupaten/kota, hasil rekapitulasi KPU kab/kota (formulir DB1), direkapitulasi di KPU provinsi. Untuk pemilihan bupati/walikota, proses rekapitulasi berhenti di KPU kabupaten/kota dan untuk pemilihan gubernur berhenti di KPU provinsi.

Perhitungan suara secara berjenjang mulai dari TPS, PPK, KPU kabupaten/kota, dan KPU provinsi tersebut memerlukan waktu yang lama. Bahkan, hasil pilkada secara resmi baru bisa diumumkan dan ditetapkan setelah 14 hari. Lamanya proses tersebut dapat membuka 
ruang kecurangan dan manipulasi perhitungan suara, sehingga hadirnya teknologi diharapkan dapat mengatasi dan menutup celah tersebut. Untuk mengatasi permasalahan tersebut, KPU menggunakan teknologi informasi yang disebut Sistem Informasi Perhitungan Suara (SITUNG).

SITUNG merupakan salah satu upaya yang dilakukan KPU dalam rangka menjaga proses dan hasil pemilu yang kredibel, dengan mengedepankan transparansi dan keterbukaan informasi publik. SITUNG menjadi sebuah instrumen untuk mengumpulkan data perolehan suara peserta pilkada yang dituangkan dalam formulir Model C dan lampirannya mulai dari tingkat TPS. Alur dari proses SITUNG tersebut dapat dilihat pada tabel berikut.

\begin{tabular}{|l|l|}
\hline TPS & $\begin{array}{l}\text { Mencatat rekap hasil perhitungan suara ke dalam } \\
\text { form C1. Memasukkan form C beserta lampirannya } \\
\text { ke sampul khusus dan disegel lalu mengirimkannya ke } \\
\text { PPS. }\end{array}$ \\
\hline PPS & $\begin{array}{l}\text { Menerima dan mengumpulkan form C1 dari seluruh } \\
\text { TPS dan mengirimkan ke PPK pada hari yang sama } \\
\text { diterimanya. }\end{array}$ \\
\hline PPK & $\begin{array}{l}\text { Menerima dan mengumpulkan form C dari seluruh } \\
\text { PPS dan mengirimkan ke KPU kab/kota pada hari } \\
\text { yang sama diterimanya. } \\
\text { Mengirimkan form DA1 (hasil rekap ditingkat PPK) } \\
\text { dalam bentuk file excel ke KPU kab/kota, ketika selesai } \\
\text { melakukan rekapitulasi di tingkat PPK. }\end{array}$ \\
\hline
\end{tabular}




\begin{tabular}{|l|l|}
\hline KPU Kab/ & \begin{tabular}{l} 
Menerima dan memindai rekap hasil perhitungan \\
suara atau form C dari masing-masing TPS dalam \\
bentuk image. \\
Menerima dan mengumpulkan form DA1 dari seluruh \\
PPK di wilayah kerjanya. \\
Mengirimkan form C dalam bentuk image, form DA1, \\
dan form DB1 (hasil rekap di tingkat KPU kab/kota) \\
dalam bentuk excel melalui aplikasi ke server KPU \\
Pusat. \\
\hline KPU
\end{tabular}$\quad \begin{array}{l}\text { Menerima form DC1 ( hasil rekap di tingkat provinsi), } \\
\text { DAsat DB1, dan form C dari KPU kab/kota melalui } \\
\text { server dan menayangkannya ke web KPU. }\end{array}$ \\
\hline
\end{tabular}

SITUNG yang digunakan pada pilkada 2018 merupakan pengembangan dari SITUNG yang digunakan pada pemilu 2014 dan pengembangan SITUNG pada pilkada 2015 dan 2017. Ada beberapa perubahan pada fitur SITUNG, yaitu tidak hanya menampilkan image hasil scan formulir $\mathrm{C} 1$ yang asli, namun memberikan informasi hasil perhitungan suara yang lebih cepat berupa data grafis yang dapat diakses oleh masyarakat untuk melihat hasil perolehan sementara di setiap daerah yang melaksanakan pilkada melalui laman infopemilu. go.id.

SITUNG pada pemilu 2014 hanya menyediakan informasi berupa gambar (image) dari formulir Model C1 dan formulir rekapitulasi perhitungan suara di semua tingkatan. Fungsi SITUNG sampai dengan saat ini masih terbatas pada pemberian layanan tambahan kepada masyarakat untuk mengetahui hasil pemilihan dengan cepat, tetapi bukan merupakan hasil pemilihan yang resmi yang akan ditetapkan oleh KPU. 
SITUNG yang dikembangkan pada pemilu 2014 berdasarkan hasil evaluasi sistem serupa pada pemilu 2004 dan 2009. SITUNG 2014 pada umumnya tidak jauh berbeda dengan pemilu 2004 dan 2009, berjalan secara stand alone dan berbasis aplikasi offline (local), scanner/ pemindai, dan aplikasi tabulasi excel. Meski perangkat dan teknologi yang digunakan sama dengan 2009, tetapi pada pemilu 2014 KPU tidak lagi menggunakan teknologi ICR yang mampu melakukan pembacaan dan rekapitulasi secara otomatis. Hasilnya dialihkan kepada output yang berupa image, yang kemudian ditampilkan di website KPU untuk bisa diakses oleh masyarakat. Walaupun model teknologi informasi yang digunakan pada SITUNG 2014 lebih sederhana, tetapi akurasinya terjamin.

Keputusan KPU untuk memublikasikan formulir Model C1 ini mendapat apresiasi luar biasa dari masyarakat dan peserta pemilu. Dengan cara tersebut, KPU tidak saja mengedepankan prinsip transparansi dalam perhitungan suara, tetapi juga memungkinkan setiap orang untuk mengecek kebenaran hasil perhitungan suara di setiap TPS, seperti yang dilakukan oleh "Kawal Pemilu", yaitu sekelompok masyarakat yang ikut berpartisipasi dalam proses pengawalan hasil pemilu dengan turut serta menghitung hasil pindaian formulir Model C1 tersebut. 


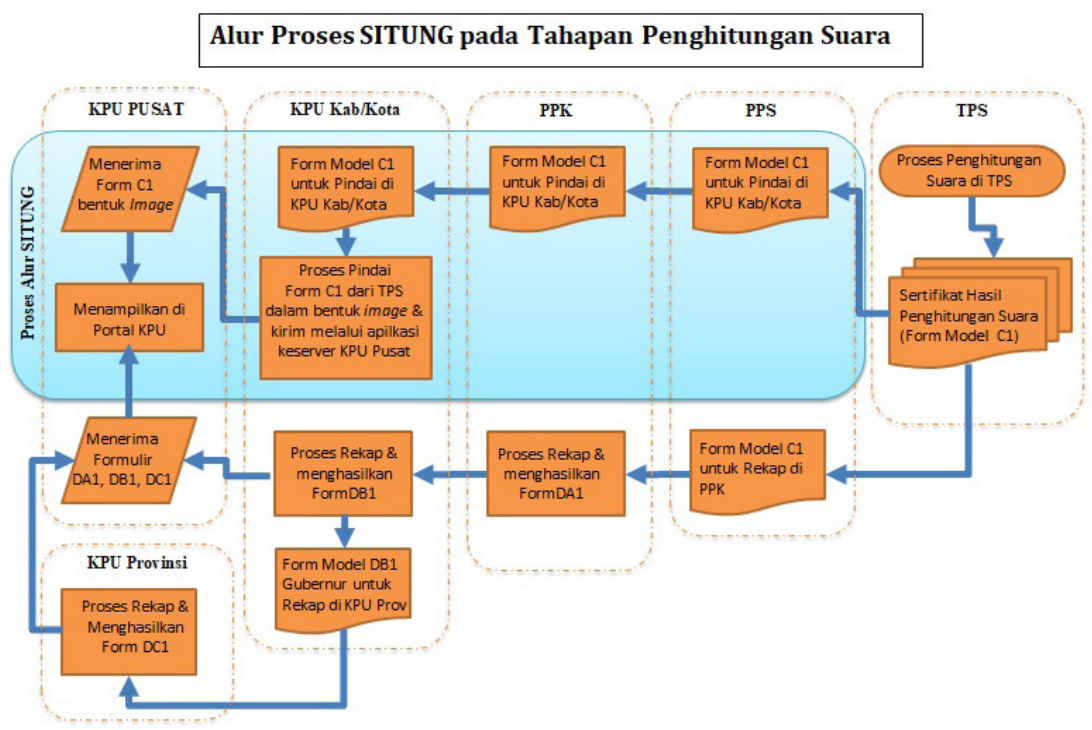

Sumber: Peraturan KPU Nomor 9 Tahun 2018 tentang Rekapitulasi Hasil Perhitungan Suara dan Penetapan Hasil Pemilihan Gubernur dan Wakil Gubernur, Bupati dan Wakil Bupati, dan/atau Walikota dan Wakil Walikota

Skema di atas merupakan alur bekerjanya aplikasi SITUNG pada proses perhitungan suara dari tingkat PPS sampai dengan KPU Pusat, mulai dari proses input sampai dengan output yang kemudian dipublikasikan secara serentak melalui portal infopilkada.kpu.go.id, dimana hasil yang diperoleh di masing-masing tingkatan terpusat dalam satu database. KPU menargetkan bahwa hasil perhitungan suara di tingkat TPS di seluruh daerah yang melaksanakan pilkada dapat langsung dipublikasikan pada hari $\mathrm{H}$ setelah ditetapkan oleh KPPS. Oleh karena itu, faktor kecepatan sangat diperlukan dalam proses tersebut, hal ini dimaksudkan agar hak-hak warga negara 
akan keterbukaan memperoleh informasi tidak terenggut. ${ }^{19}$ Selain itu, SITUNG merupakan media untuk memutus praktik manipulasi hasil perolehan suara, sehingga KPU bisa menjaga tingkat akurasi data dalam penyelenggaraan pemilu. ${ }^{20}$ SITUNG juga didesain untuk menjadi sarana KPU dalam membuat arsip digital pemilu yang tadinya berwujud fisik, seperti formulir C1, DAA, DA1, DB1, dan DC1 ke dalam bentuk softfile, seperti image maupun file excel. Dan juga, SITUNG memiliki desain untuk tabulasi nasional hasil perhitungan suara seperti yang dilakukan pada pemilu-pemilu sebelumnya.

SITUNG telah menstimulasi masyarakat untuk melakukan proses pengawalan dan pengawasan proses rekapitulasi hasil perhitungan suara yang dilakukan secara berjenjang. Aplikasi ini membuat masyarakat aktif untuk melaporkan kesalahan atau ketidakakuratan maupun potensi kecurangan yang terjadi pada Model C1. KPU pun membuka layanan aduan untuk kemudian divalidasi dan menyampaikan kepada KPU provinsi, KPU kabupaten/kota yang bersangkutan untuk memperbaiki sesuai aduan masyarakat dan menyampaikannya kembali setelah masalahnya ditindaklanjuti.

Dari penjelasan di atas, dapat dilihat bahwa SITUNG masih digunakan sebagai bentuk pelengkap dari proses perhitungan suara resmi secara manual. Dengan demikian, penggunaan teknologi dalam SITUNG masih sebagai pendamping dan pelengkap sehingga masuk kategori penetrasi sebagai tools.

19 Andi Syahruddin Alam \& Muh. Iqbal Sultan. (2016). Keterbukaan Informasi Publik Melalui Sistem Penghitungan (SITUNG) Online Hasil Pilkada Terhadap Pengetahuan, Sikap, Dan Perilaku Masyarakat Di Kota Palu. Jurnal Komunikasi KAREBA, Vol. 5, No. 1, Januari-Juni 2016, 93.

20 Ibid, 94. 


\section{Kesimpulan dan Saran}

Berdasarkan analisis di atas, penetrasi pemanfaatan teknologi informasi dalam tahapan pilkada dapat dikatakan sudah cukup ideal untuk menjawab kebutuhan akan efisiensi, efektivitas, transparansi, dan akuntabilitas, dimana terpenuhinya SITUNG dalam kategori tools sedangkan SIDALIH termasuk dalam kategori enabler. Selanjutnya, untuk pengembangan pemanfaatan teknologi dalam pemilihan umum di Indonesia untuk menjadi transformer harus melalui kajian yang sangat mendalam dari berbagai aspek. Syarat utamanya adalah tidak melanggar lima asas pemilu, yaitu langsung, umum, bebas, rahasia, jujur, dan adil. Mahkamah Konstitusi juga memberikan perintah bahwa penggunaan teknologi informasi harus didahului oleh kajian yang mendalam, serangkaian uji coba, kesiapan peralatan, SDM, dan masyarakatnya.

Titik awal untuk mengevaluasi teknologi tidak boleh menjadi teknologi mana yang dipilih atau bagaimana mengimplementasikannya. Tetapi, berdasarkan kebutuhan menyelesaikan masalah pada tahapan pemilihan mana yang perlu ditangani dan bagaimana cara terbaik untuk melakukannya. Pemilihan apa dan jenis teknologi yang hendak digunakan dalam pelaksanaan tahapan pilkada adalah hal yang mendasar untuk dirumuskan.

Pengadopsian bentuk inovasi teknologi ke dalam proses penyelenggaraan pilkada hendaknya direncanakan dengan matang dengan memperhatikan efektivitas dan efisiensi. Dengan demikian, perlu dilakukan evaluasi untuk merumuskan persoalan-persoalan secara nasional dengan kebijakan yang dapat diimplementasikan secepatnya. Berbagai persoalan terkait penyelenggaraan pilkada harus segera dicarikan jalan keluarnya supaya tidak menjadi preseden buruk bagi proses demokrasi dan pada akhirnya mengakibatkan hasil pemilihan kurang legitimate karena tidak bisa diterima dengan baik 
oleh semua komponen warga negara.

Pemanfaatan teknologi informasi dalam proses pemilu maupun pilkada akan selalu diperlukan. Sebab, dalam penyelenggaraannya melibatkan jutaan pemilih dengan sistem pendataan yang rumit dan basis data yang besar sehingga teknologi yang positif seakan menjadi keharusan. Dengan teknologi, kealpaan manusia dapat dihindari, dan upaya preventif untuk mengatasi fraud yang dilakukan peserta dan petugas dapat dimaksimalkan. Ada beberapa hal umum yang harus dipertimbangkan dalam implementasi teknologi untuk proses pemilihan, di antaranya:

1. Penerapan teknologi pada pemilu dan pilkada bisa menjadi aktivitas yang berisiko tinggi, maka harus dilakukan dengan benar, terbuka untuk pengawasan publik, dan tidak ada banyak ruang untuk melakukan kesalahan. Kemudian, perlu dilakukan beberapa kali pengujian atau trial and error. Tidak seperti aplikasi teknologi lainnya, dimana sistem dapat diperkenalkan secara bertahap dengan pengujian yang panjang jauh dari jadwal pelaksanaan, sebagian besar sistem informasi dalam pemilu maupun pilkada yang digunakan, dibuat dalam waktu yang mendekati deadline suatu proses tahapan, seperti SIDALIH dan SITUNG. Imbasnya adalah pada saat digunakan tidak bisa tampil dengan maksimal sehingga mengurangi performa kinerja penyelenggara.

2. Badan manajemen pemilu perlu mempertimbangkan inovasi teknologi yang baru. Evaluasi menyeluruh diperlukan untuk menghindari timbulnya biaya tinggi untuk perbaikan yang relatif kecil. Tergantung pada aplikasinya yang akan terus mengalami perubahan sesuai dengan kebutuhan yang ada.

3. Pertimbangan efektivitas biaya penerapan teknologi baru. Studi evaluasi biaya dan penghematan yang terkait dengan pengenalan 
teknologi baru perlu dipertimbangkan. Tidak hanya biaya awal yang terlibat dalam pembelian peralatan dan material, tetapi juga biaya untuk menyiapkan sistem baru, keahlian tambahan, dan kebutuhan untuk pemeliharaan, serta pengelolaan yang berkelanjutan.

4. Pertimbangan mengenai keberlangsungan teknologi yang sedang dievaluasi. Dalam sebagian besar aplikasi, ada kebutuhan untuk memastikan bahwa teknologi yang diadopsi dapat digunakan untuk beberapa periode pemilihan ke depannya. Mengadopsi teknologi yang dapat menjadi cepat usang atau tidak dapat digunakan mungkin akan telihat mahal dan tidak memiliki keberlanjutan dalam jangka panjang. Disrupsi teknologi membuat teknologi berubah dengan sedemikian cepat sehingga hampir tidak mungkin untuk menghindari keusangan dalam jangka pendek. Dalam hal ini, penting untuk mempelajari standar dan tren teknologi yang ada untuk kemudian mengadopsinya pada sistem yang akan datang.

5. Faktor kepercayaan terhadap keamanan pada teknologi informasi yang digunakan, sangat memengaruhi kredibilitas pilkada. Masyarakat di era Milenium adalah masyarakat yang sangat kritis. Namun, pemahaman masyarakat terhadap penggunaan teknologi informasi masih rendah sehingga memengaruhi kepercayaan masyarakat terhadap hasil pilkada secara keseluruhan. Oleh karena itu, upaya meningkatkan literasi digital masyarakat menjadi tugas berikutnya yang harus dilakukan oleh penyelenggara pilkada melalui kegiatan sosialisasi yang melibatkan seluruh segmen masyarakat.

6. Kepastian akan landasan hukum dalam Undang-undang untuk penggunaan teknologi informasi sehingga mendapatkan efek kepatuhan dari stake holders terkait. 


\section{Referensi}

Alam, Andi Syahruddin \& Sultan, Muh. Iqbal. (2016). Keterbukaan Informasi Publik Melalui Sistem Perhitungan (SITUNG) Online Hasil Pilkada Terhadap Pengetahuan, Sikap, dan Perilaku Masyarakat di Kota Palu. Jurnal Komunikasi KAREBA, Vol. 5, No. 1, Januari-Juni 2016, 93.

Alvarez, R. M., Thad E. Hall, and Alexander H. Trechsel. (2009). Internet Voting in Comparative Perspective: The Case of Estoni. Political Scienc and Politics, Vol. 42, No. 3, July 2009, 497-505.

Alvian. (1991). Rethinking of Cities, Culture and Tourism within a Creative Perspective. Editorial dari PASOS, Vol. 8 (3), Special Issue 2010, 06-16.

Berinsky, A. J. (2005). The perverse consequences of electoral reform in the United States. American Politics Research, 33 (4), 471-491.

Budiardjo, Mirriam. (2008). Dasar-dasar Ilmu Politik. Edisi Revisi. Jakarta: Gramedia Pustaka Utama.

Cushing, Barry E. (1993). Accounting Information System and Organization. Edisi Tiga. Ruchyat Kosasih (penerj.). Jakarta: Penerbit Erlangga.

Gatara, Sahid. (2009). Ilmu Politik, Memahami dan Menerapkan. Bandung: Pustaka Setia.

Heywood, Andrew. (2013). Politik Edisi Keempat. Yogyakarta: Pustaka Pelajar.

Huntington, Samuel P. (1991). Gelombang Demokrasi Ketiga. Jakarta: Grafiti.

Huntington, Samuel P. dan Joan Nelson. (1994). Partisipasi Politik di Negara Berkembang. Jakarta: Rineka Cipta. 
Husein, Harun. (2014). Pemilu Indonesia: Fakta, Angka, Analisis dan Studi Banding. Jakarta: Perludem.

IDEA. (2006). Desain Penyelenggaraan Pemilu. Buku Pedoman Internasional IDEA, 257-283.

Indriantoro Nur. (2000). Sistem Informasi Strategik: Dampak Teknologi Informasi terhadap Organisasi dan Keunggulan Kompetitif. Jurnal KOMPAK, No. 9, Pebruari.

Kasali, Rhenald. (2017). Disruption: Tak Ada yang Tak Bisa Diubah Sebelum Dihadapi Motivasi Saja Tidak Cukup. Jakarta: Gramedia Pustaka Utama.

Komisi Pemilihan Umum. (2017). Inovasi Pemilu: Mengatasi Tantangan Memanfaatkan Peluang. Jakarta: Tanpa Penerbit.

Marsh, David and Gerry Stoker. (2002). Theory and Methods in Political Science. New York: Palgrave McMillan.

McCormak, Conny. (2016). Democracy Rebooted: The Future of Technology in Elections. Washington: Atlantic Council.

Nugroho, Lukito Edi. (2009). Pemanfaatan Teknologi Informasi di Perguruan Tinggi. Yogyakarta: Prajnya Media.

Perludem. (2017). Evaluasi Pemilu 2017: Pemilu Transisi Gelombang Kedua Menuju Pemilu Serentak Nasional. Jurnal Pemilu dan Demokrasi, \#10.

Perludem. (2016). Kodifikasi Undang-Undang Pemilu Pembaruan Hukum Pemilu Menuju Pemilu Serentak Nasional dan Pemilu Serentak Daerah. Jurnal Pemilu dan Demokrasi, \#9.

Sardini, Hidayat Nur. (2017). Mengeluarkan Pemilu dari Lorong Gelap. Jakarta: Pustaka Obor Indonesia. 
Sugiyono. (2016). Metode Penelitian Pendidikan (Pendekatan Kuantitatif, Kualitatif, dan R\&D). Bandung: Alfabeta.

Surbakti. Ramlan, Didik Supriyanto, dan Hasyim Ashari. (2011). Meningkatkan Akurasi Daftar Pemilih: Mengatur Kembali Sistem Pemilih Pemutahiran Daftar. Jakarta: Kemitraan bagi Pembaruan Tata Pemerintahan.

Vassil, Kristjan. (2011). Voting Smarter? The Impact of Voting Advice Applications on Political Behavior. Eropa: European University Institute.

Vassil, K. \& T. Weber. (2011). A Bottleneck Model of E-Voting: Why Technology Fails to Boost Turnout. New Media \& Society, 13 (8), 1336-1354.

Vickery, Chad., David Ennis, Katherine Ellena, and Alyssa Kaiser. (2018). When Are Elections Good Enough? Validating or Annulling Election Results. Tanpa Kota: International Foundation for Electoral Systems (IFES). 